\title{
The Impact of Budgeting As a Control Mechanism in Banking Industry: A Case Study of a Nigerian Bank
}

\author{
${ }^{1} \mathrm{Abu}-$ Saeed Munirat and ${ }^{2} \mathrm{Abu}-$ Saeed Muslimat \\ ${ }^{I}$ Department of Banking and Finance, Kogi State University, Ayingba. Nigeria \\ ${ }^{2}$ Department of Accounting, Kogi State Polytechnic, Lokoja. Nigeria
}

\begin{abstract}
The bank industry in Nigeria has been facing an increasing hostile environment of the business compare to other sectors of industry and what led to these problem are their inability to meet up the proposed budget poor forecasting of future events like inflation and poor control of reported variants. Thus, this work tends to investigate how a Nigerian bank prepares and executes its budget and also how the impact and variances are reported for control purpose. A total of 46 respondents were selected using simple random sampling from the staffs of different branches of a Nigerian bank. Semi structured questionnaires were administered and analysed. Data were presented in form of tables. Two hypotheses were tested for using chi square analysis. This study reveals that budget preparation was carried out in the branches of the bank and that managers are the personnel responsible for the preparation and implementation of budget. It also revealed that the bank has a budget committee and that on the average budgets are actualized. Budget failure according to respondents was caused by poor implementation and forecasting. There was a significant relationship between budget and control mechanism in the banking industry and there was also a significant relationship between budget preparation and budget implementation in the banking industry. This study thus shows that budgeting has a great impact on the control mechanisms in banking industry.
\end{abstract}

\section{Introduction}

The process of preparing and using budgets to achieve management objective is called budgeting. Budgeting is an essential element which is vital to management accounting techniques which can benefit all the aspect of business if it is understood and properly used. A budget is a qualitative expression of plan (Shillinglaw, 1977). It could also be defined as the plan or dominant individual in an organization expressed in monetary terms and subjects to the constraints imposed by their participants and the environment indication on how the available resources may be utilized to achieve whatever the dominant individuals agree to be the organizations priorities (Omolehinwa, 1991). Owler and Brow (1984) further explained that budgeting control is seemed to be related to the standard costing but they are independent. Wildarsky (1964) argue that because a budget served diverse purposes, it can mean different things to different people. Among the various possible interpretations given by him include: plan to work, prediction, link between financial resources and human behaviour to accomplish policy objectives and mechanism for making choice among alternative expenditure. However, business enterprises must plan ahead to survive and achieve its objective. It is therefore essential that every organisation determines what is to be done today to realize tomorrow's dream of the owners of the company.

The Chartered Institute of Management Accountants (CIMA) defined budgeting control as the establishment of budgeting relating the responsibilities of the executives to the requirements of a policy and the continuous comparism of actual with budgeted results either to source by individual actions of the objectives of that policy or to provide a basis for its revision.

Planning is the process of establishing goals and objectives and the courses of action to attain them. Planning does not guarantee organisational success because an organisation that may fall due to faulty performance of function of organizing, motivating and controlling. Several studies in business have made known the usefulness of budgeting especially for planning and control purposes. Anorld (1987) believe in performance measurement through the comparism of variables besides profit and cash. Therefore, the assessment of the performance of individual management blocks as to depend on clearly defined objectives. In budgeting, the budgeters must know the company's areas of excellence, area of monopolistic power, areas of competence, competition and weakness. To ensure that a realistic budget is produced and the company must know the existing and foreseeable threats and opportunities in their operating environment.

The bank industry in Nigeria has been facing an increasing hostile environment of the business compare to other sectors of industry and what led to these problem are their inability to meet up the proposed budget poor forecasting of future events like inflation and poor control of reported variants. Thus, this work tends to investigate how a Nigerian bank prepares and executes its budget and also how the impact and variances are reported for control purpose. 


\section{Method}

Zenith Bank of Nigeria Plc was used as the case study. It was incorporated as a private limited liability company by a group of Nigerians in 1990. It has not less than 15 branches within Lagos. The bank is engaged in the provision of universal banking services to corporate, commercial and individual customers. It provides banking services such as savings and current accounts, treasury and financing, fund management, import and export financing among other.

The entire population considered were five selected branches of the bank (three old branches and two new branches) in order to ascertain the views on the impact of budgeting as a control mechanism in banking industry. Simple random sampling was used for the respondents that participated in this research work and a 50 staffs from a total of about 350 staffs were selected. Semi structured questionnaire were administered to respondents. Data collected from the questionnaires were analysed and presented in form of table, percentages and test for hypotheses using chi square at $95 \%$ level of significance.

Two hypotheses were tested for to guide in the discussion. These include:

1. $\mathbf{H}_{\mathbf{0}}$ : There is no significant relationship between budgeting and control mechanism in the banking industry

$\mathbf{H}_{\mathbf{1}}$ : There is significant relationship between budgeting and control mechanism in the banking industry

2. $\mathbf{H}_{0}$ : There is no significant relationship between budgeting preparations and budgeting implementation in the banking industry

$\mathbf{H}_{1}$ : There is significant relationship between budgeting preparation and budgeting implementation in the banking industry.

\section{Results}

Out of the 50 questionnaires distributed, 46 of them were answered and returned. Table 1 presents the socio demographic data of the respondents. Out of 46 respondents, 37 of them were males while 9 were females. Also, $5(10.9 \%)$ of the respondents were branch managers, 16 (34.8\%) were supervisors, 13 (28.3\%) were Head of departments and $12(26.1 \%)$ were directors. The academic qualifications of the respondents included NCE $(10 ; 21.7 \%)$, B.Sc $(20 ; 43.5 \%)$, OND $(10 ; 21.7 \%)$ and others $(6 ; 13 \%)$ were professionals.

Table 1: Socio demographic data of respondents

\begin{tabular}{ll}
\hline Data & Frequency $\mathbf{n}=\mathbf{4 6}(\boldsymbol{\%})$ \\
\hline Age in years & \\
$21-30$ & $23(50.0)$ \\
$31-40$ & $15(32.6)$ \\
41 and above & $8(17.4)$ \\
$16-18$ & $10(2.5)$ \\
& \\
Working experience in years & \\
$1-3$ & $15(32.6)$ \\
$4-6$ & $13(28.3)$ \\
$7-9$ & $12(26.1)$ \\
10 and above & $6(13.0)$ \\
\hline
\end{tabular}

Thirty five $(76.1 \%)$ of the respondents said that the bank prepares budget while $11(23.9 \%)$ said that the bank does not prepare budget. Majority of the respondents $(39 ; 84.8 \%)$ agreed that budget planning have impact in the bank while the remaining $7(15.2 \%)$ said it does not. According to the respondents, impact or effects of budgeting across organisations include unwanted pressure $(33 ; 71.7 \%)$ and groups $(13 ; 28.3 \%)$. When respondent $\mathrm{s}$ were asked if there is a relationship between budget preparation and implementation in the bank, $30(65.2 \%)$ of them agreed while $16(34.8 \%)$ of them disagreed.

According to the respondents, senior managers only $(7 ; 15.2 \%)$, all managers $(38 ; 82.6 \%)$ and all managers down to the staffs $(1 ; 2.2 \%)$ were responses given when they were asked those that were responsible for budget preparation in the bank. In addition, $32(69.6 \%)$ of the respondents said that there was a budget committee while $14(30.4 \%)$ said there was no budget committee. Twenty eight $(60.9 \%)$ said that there is significant relationship between budgeting and control mechanism in the banking industry while $18(39.1 \%)$ disagreed. Majority of the respondents $(38 ; 82.6 \%)$ said that the activities of the organisation was in line with planned budget while $8(17.4 \%)$ of them agreed otherwise.

About half $(26 ; 56.5 \%)$ of the respondents said that the budget planned were actualized while the remaining $(20 ; 43.5 \%)$ said that the budget planned were not actualized. Budgeting in the bank were in conformity with what is written in the literature according to $29(63.0 \%)$ respondents while $17(37.0 \%)$ said they were not in conformity. When respondents were asked the reasons for budget failure, two reasons were proffered: poor implementation $(32 ; 69.6 \%)$ and poor forecasting $(14 ; 30.4 \%)$. 
Table 2 shows the calculated chi square to test if there is a significant relationship between budgeting and control in the banking industry using results obtained from respondents while table 3 shows the calculated chi square test if there is significant relationship between budgeting preparation and implementation in the banking industry. The calculated chi square was determined thus:

$\mathrm{X}^{2}=\sum \frac{(\mathrm{Fo}-\mathrm{Fe})^{2}}{\mathrm{Fe}^{2}}$

$\mathrm{Fe}$

Where $\mathrm{Fo}=$ Observed frequency

$\mathrm{Fe}=$ Expected frequency

$\mathrm{X}^{2}=$ Chi square determined

Table 2: Testing for significant relationship between budgeting and control in the banking industry

\begin{tabular}{|l|l|l|l|l|l|l|l|l|}
\hline $\begin{array}{l}\text { Respondents' } \\
\text { options }\end{array}$ & $\mathbf{F}_{\mathbf{o}}$ & $\mathbf{F}_{\mathbf{e}}$ & $\mathbf{F}_{\mathbf{0}}-\mathbf{F}_{\mathbf{e}}$ & $\left(\mathbf{F}_{\mathbf{0}}-\mathbf{F}_{\mathbf{e}}\right)^{2}$ & $\left.\underline{\mathbf{F}_{\mathbf{0}}}-\overline{\mathbf{F}}_{\mathbf{e}}\right)^{2}$ & $\mathbf{D f}$ & $\mathbf{X}^{2}$ calculated & $\begin{array}{c}\mathbf{X}^{2} \text { tabulated (level of } \\
\text { significance= 0.95) }\end{array}$ \\
\cline { 1 - 6 } Yes & 28 & 23 & 5 & 25 & 1.087 & \multirow{2}{*}{1} & 2.174 & 0.004 \\
\hline No & 18 & 23 & -5 & 25 & 1.087 & & & \\
\hline Total & 46 & 46 & 0 & & 2.174 & & & \\
\hline
\end{tabular}

Table 3: Testing for significant relationship between budget preparation and implementation in the banking industry

\begin{tabular}{|c|c|c|c|c|c|c|c|c|}
\hline $\begin{array}{l}\text { Respondents' } \\
\text { options }\end{array}$ & $\mathbf{F}_{\mathbf{o}}$ & $\overline{F_{e}}$ & $F_{0}-F_{e}$ & $\left(F_{0}-F_{e}\right)^{2}$ & $\underline{\left(\mathbf{F}_{0}-\underline{F_{\mathrm{e}}}\right)^{2}} \underline{\mathbf{F}}_{\mathrm{e}}$ & df & $\mathrm{X}^{2}$ calculated & $\begin{array}{l}\mathrm{X}^{2} \text { tabulated (level of } \\
\text { significance }=0.95 \text { ) }\end{array}$ \\
\hline Yes & 30 & 23 & 7 & 49 & 2.130 & \multirow[t]{3}{*}{1} & \multirow[t]{3}{*}{4.260} & \multirow[t]{3}{*}{0.004} \\
\hline No & 16 & 23 & -7 & 49 & 2.130 & & & \\
\hline Total & 46 & 46 & 0 & & 4.260 & & & \\
\hline
\end{tabular}

\section{Discussion}

Out of the 50 questionnaires administered, 46 were filled. This shows that a very good number of the questionnaire were filled which is okay for further analysis. Majority of respondents were male. This may be as a result of tedious nature of banking in Nigeria which tends to discourage a lot of females from going into banking. All age groups were well represented ranging from young to old respondents. This gives a room to sample opinions across all age groups and not limited to only certain age groups. The rank distribution of respondents shows that the ranks also cut across the major decision makers of the bank especially as it concerns budgeting. Opinions obtained from the questionnaire are therefore those of workers directly or indirectly concerned with budgeting which can give a true picture of budgeting in the bank. Also, the years of experience of the respondents also cuts across both young and old staffs. This also gives the opportunity to sample across wide range of years of experience.

Almost all the respondents agreed that budget planning have an impact on the bank and majority gave unwanted pressure as the major impact. Results obtained from this study also points to the fact that about one third of the respondents said there was no relationship between budget preparation and implementation. Although majority viewed it otherwise, the percentage is a bit high. Implementation of budget goes a long way to enhance the management of an organisation because it has been termed as an indispensable management aid for directing, coordinating and controlling the activities of firms under public and private sectors (Pendlebury, 1984). If budget is not implemented, it affects aspects like communication, planning, coordination and control. Majority of respondents also said that all managers are involved in budgeting. This is a good trend because coming together of all the managers may give a better outcome during budget preparation which may enhance proper management of the bank. Majority of the respondents pointed out the fact that the bank has a budget committee. This is a good step because budget committee helps to set the general guidelines that the organisation is to follow in budget preparation. Almost all the respondents said that the activities of the organization are in line with planned budget. This gives the bank focus on proper management. Just about half of the respondents said those planned budgets are actualized and possible reason given included poor implementation and forecasting.

The testing of hypotheses used for this study revealed that when the relationship between budgeting and control mechanism in the banking industry was tested, the result showed that the $\mathrm{X}^{2}$ value calculated was greater than the tabulated $\mathrm{X}^{2}$. This effect means that the null hypothesis $\mathrm{H}_{0}$ is rejected thereby accepting the alternative hypothesis $\mathrm{H}_{1}$. This implies that from the analysis, there is a significant relationship between budgeting and control mechanism in the banking industry.

Also, the hypothesis which states that there is no significant relationship between budget preparation and budget implementation in the banking industry. When this was tested with chi square distribution and at $95 \%$ level of significance, the result showed that chi square value was 4.26 while chi square tabulated was given as 0.004 . This in effect means that the null hypothesis $\mathrm{H}_{0}$ is rejected, thereby accepting the alternative 
hypothesis $\mathrm{H}_{1}$. This implies that from the analysis, there is a significant relationship between budget preparation and budget implementation in the banking industry.

\section{Conclusion}

This study reveals that budget preparation was carried out in the branches of the bank and that managers are the personnel responsible for the preparation and implementation of budget. It also revealed that the bank has a budget committee and that on the average budgets are actualized. Budget failure according to respondents was caused by poor implementation and forecasting. There was a significant relationship between budget and control mechanism in the banking industry and there was also a significant relationship between budget preparation and budget implementation in the banking industry.

\section{References}

[1]. Arnold, E. (1987). Performance measurement and the need for comparism. Management accounting. 65 (2):228

[2]. Chartered Institute of Management Accountants (ICMA) (1984). Official Technology of Management Accounting. London: 58.

[3]. Omolehinwa, E. (1991). Coping with Cost Accounting. Pumark Nigeria Limited:297

[4]. Owler, L.M. and Brown, L. (1984). Wheldons cost Accounting (5 ${ }^{\text {th }}$ Edition). Evans London:344

[5]. Pendlebury, S. M. (1984). Budgetary Control and Implementation:320

[6]. Shillinglaw, G. (1977). Managerial Cost Accounting. Richard D. and Erwin Home world:234

[7]. Wildarsky, A. (1964): The Politics of budgetary process, little Brown and company, Boston: 213 